\title{
Improving Students' Scientific Arguments Guided Inquiry Ability Through Student Textbook
}

\author{
Bagus R Wijaya \\ Pendidikan Sains \\ Universitas Negeri Surabaya \\ Surabaya, Indonesia \\ bagusrwijaya@mhs.unesa.ac.id
}

\author{
Yuni Sri Rahayu \\ Pendidikan Sains \\ Universitas Negeri Surabaya \\ Surabaya, Indonesia \\ yunirahayu@unesa.ac.id
}

\author{
R Agustini \\ Pendidikan Sains \\ Universitas Negeri Surabaya \\ Surabaya, Indonesia \\ rudianaagustini@unesa.ac.id
}

\begin{abstract}
Student of pre-service biology teacher should be able to hold the scientific facts discovered through the inquiry process using scientific argument. The purpose of this study was to facilitate students' scientific arguments ability through guided inquiry-based learning. The approach adopted in this study facilitates the ability of scientific argument indicator integrated into guided inquiry-based learning. The study conducted on respondents $(n=12)$ aims to examine the effectiveness of textbook was developed. The study design using One Group Pretest Posttest Design. The results showed that the application of guided inquiry-based textbook developed by researchers can facilitate scientific argument ability of students have the value of $\mathrm{N}$-Gain 0.71 with the high category.
\end{abstract}

Keywords- Student scientific argument; Guided inquiry abilit; Pre-service teacher; Biology education

\section{INTRODUCTION}

In recent years, their science lessons focused on providing opportunities for students involved and learn to use scientific thinking skills. Experts teach science concepts rather than as a product of science, but through the construction of argumentative skills which are the characteristic of scientific inquiry [1] [2] [3]. This is due to the importance of the ability to build a knowledge through argumentative ability based on new evidence is found. The emergence of this new evidence makes the researcher must be able to provide an explanation argumentative to consider the existence of theories, models, and law preexisting [4]. The conditions make learning should be taught to students with how to think and are acting as a researcher [95].

Students must learn how to be a researcher to construct knowledge through scientific inquiry [5]. As a researcher, students should be able to make inquiries, analyze the data, explain the facts, make a conclusion, and retain its findings [6]. It can be concluded that the students should be able to explain its findings through the argumentation ability. The argument has a main role in developing, evaluating, and validating knowledge. students can engage in learning by providing evidence, data, and valid theory using scientific arguments to corroborate claim made through scientific inquiry activity [7].

Arguments can serve to control the match between the claim with evidence or phenomenon. The argument is a measure of the validity of the claim made [8]. Students can use scientific arguments to explain a phenomenon, communicating knowledge and influence the mindset of others about a fact. The use of scientific argument has a goal to make the claim and made an excuse to claim being made, asking questions, challenge and revise the claim is made, provide evidence and argumentation of the claim [9]. Kuhn and Reiser ([10]) found that students find difficulties to use scientific arguments. The difficulties occur because, they should make an appropriate claim, gives grounds to support the claim, linking findings with the concept, and deliver what they understand [11]. Schan filed five indicators of scientific arguments, such as making inferences based on data (claims), said data being used and analyze the data (grounds used), providing security against claims made (warrant), making inferences alternative (counterargument generated), made in response to alternative views are made (rebuttal offered) on the issue [12].

The previous study states that the scientific arguments that build science foundation of science [6] [13] [14]. The ability of a scientific argument is well aligned with the model of inquiry and it is typical of science learning [15]. Scientific arguments can be taught through guided inquiry. Statement researchers had previously stated that the argument is an important aspect of inquiry-based learning, but often not practiced [16]. The Scientific argument is the main aspect of developing, evaluating, validating scientific knowledge is a differentiator from other science [18]. 
Another study supports that capability scientific arguments can be drilled through the inquiry. Hsu et al. Argumentative concluded that learning Scientific Inquiry System can facilitate the ability to build a scientific argument. The study conducted by Katchevich et al [17], demonstrated that the experimental inquiry-based learning has effective to facilitate scientific argument ability in the study of the environment [17]. Pickles and Patton application inquiry model can improve the ability of the student's argument [2]. Other studies Wilson et al found inquiry model better than conventional model to facilitating scientific argument ability [18]. Research conducted by Farida found argumentative inquiry learning can facilitate scientific argument ability of students [21]. The studies that have been done are the basis of this study. However, previous studies have not used guided inquiry. Therefore, researchers conducted a study to develop a student textbook on plant transport in the course of plant physiology that effective to facilitate scientific argument ability of students.

\section{STUDY METHODS}

Design in this study using One Group Pretest Posttest Design. Before doing the learning, students asked to complete a pretest to determine the initial ability of students in mastering the scientific argument. After the students have done the treatment in learning process, posttest is given to students. This test determines the ability of students in mastering the scientific argument. Questions used in the pretest and posttest are indicators of the scientific argument ability. Given problem relates to the results of experiments fact that have been done. Then the data obtained from the pretest and posttest results will be analyzed by the equation. $N$-Gain

$$
N-\text { Gain }=\frac{\text { Score postest }- \text { Score pretest }}{\text { Score maximal }- \text { Score pretest }}
$$

Values $\mathrm{N}$-Gain of student scientific argument ability can be defined by criteria scores as presented in Table 1 .

TABLE I. CRITERIA N-GAIN CHANGE SCORE

\begin{tabular}{cc}
\hline Score Range & Description \\
\hline$>0.70$ & High \\
$0.30-0.70$ & Middle \\
$<0.30$ & Low \\
\hline
\end{tabular}

Completeness indicator scientific argument ability of student was measured by using essay question that consists of 15 items. These items must have a sensitivity index value with sensitive criteria. Sensitivity index items scientific argument abilities in this study had valued between 0.22 to 0.61 with the criteria stated sensitive. Participants in this study were student of pre-service biology teacher students of third semester $(\mathrm{n}=12$, age $=19-20$ years old). Students were divided into 3 heterogeneous groups with each group consist of 4 students.

\section{RESUlTS AND DISCUSSION}

\section{A. The phase of Study}

The study was conducted in several stages which are: 1 . The phase of measurement capabilities initial arguments student (pretest); 2. The phase of learning; 3 . The phase of literature review and experiment; 4 . The phase of drafting arguments; 5 . The phase of presented the results of a literature review and experiment; 6 . The phase of measurement capability student scientific arguments end (posttest). The study was conducted in four sessions plus one posttest. The first meeting applied to phase 1 until phase 5. The second, third, and fourth meeting applied to phase 2 to stage 5 . The last meeting applied to phase 6 .

The first stage: The study begins by measuring the ability of students through the scientific arguments argument test instrument. This test instrument contains 15 questions containing indicators of students' scientific argument ability, there are the Indicators of the argument ability: make conclusions based on the data obtained (claim), mention the data being used and analyze the data (grounds used), give warrant to claims have been made (warrant), made inferences alternative (counterargument generated), made in response to the opinion alternative made (rebuttal offered) on the issue [12]. Chapter used in tests is the material that has been learned when they were $2^{\text {nd }}$ semester students, so, students have sufficient understanding of the concept to be applied in the of scientific argument

The second stage: Learning is done to learn the material on transport in plants in plant physiology course. The material consists of five sub-chapters, first sub-chapter is about the nature and structure of water, second sub-chapter is on the transport of cellular level, third sub-chapter is about the transport tissues level, fourth sub-chapter is on the transport of the organ level, fifth sub-chapter is about transport the level of the organism, and the sixth sub-chapter is about nutrients of plant. Learning implemented in four meetings.

The third stage: This stage aims to collect data on the material being studied. Students do review some literature and experiment with applying the guided inquiry-based learning. This stage consists of two kinds of activities, the first activity is to study literature and second activity by experiment. The first meeting of the student is given the problem of how to spider can stand on water without sinking. The second and fourth meetings conducted by conducting experiments, there are the diffusion and osmosis, transpiration, and water absorption by plant roots experiments.

The fourth stage: Students discussion to answer questions containing indicators of scientific argument. Students make inferences, support, warranty, and disclaimer. Students are facilitated to make scientific arguments in writing form. The first meeting, students found difficulties to connect claim with existing data (indicator 3 ). Students also had trouble with the indicators 4 and 5. This is similar to the opinion of D. Kuhn that the ability of high-level arguments rarely mastered by children and even adults [13]. In addition, students have not 
been facilitated in previous learning. The second meeting, students found difficulties at the phase of making the objection rebuttal or alternative conclusions and make a response. Students are still hard to find anything else that can be concluded from these experiments. The third meeting of student found difficulties in determining the data that should be used, because there are many data of reduction in the water volume every 10 minutes. They are confused which data should be used to determine the rate of transpiration. There is one group of students summing the difference in volume at any time. Data that should be used is the data recorded in the last time observation. The fourth meeting of the students are accustomed to using scientific argument ability, so it is not found significant obstacles.

The fifth stage: Students presented the results of the discussion to the other groups. The presentation was a means to facilitate scientific arguments ability orally. Students are more active in developing questions and answer the questions. Answers should always have a strong guarantee either derived from experimental data and the theory studied. This stage is also the guidance by the lecturers of the quality of students argumentation ability.

The sixth stage: posttest used the same type and number of questions (15) with the pretest. But both of them covering a different material. The materials on the posttest are material that has been learned at the first until four meeting.

\section{B. Textbook Developed Effectiveness}

The effectiveness of developed textbooks was analyzed from N-Gain value that derived by comparing pretest and posttest students. The following is a table of the value of $\mathrm{N}$ Gain:

\section{TABLE II. N-Gain Value Test ARgument Student Science}

\begin{tabular}{|c|c|c|c|c|}
\hline $\begin{array}{c}\text { Student' } \\
\text { Initial }\end{array}$ & Pretest & 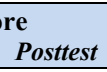 & N-Gain & Criteria \\
\hline M1 & 40.00 & 68.89 & 0.48 & Middle \\
\hline M2 & 44.44 & 84.44 & 0.72 & High \\
\hline M3 & 44.44 & 86.67 & 0.76 & High \\
\hline M4 & 37.78 & 80.00 & 0.68 & Middle \\
\hline M5 & 62.22 & 95.56 & 0.88 & High \\
\hline M6 & 51.11 & 86.67 & 0.73 & High \\
\hline M7 & 42.22 & 80.00 & 0.65 & Middle \\
\hline M8 & 48.89 & 82.22 & 0.65 & Middle \\
\hline M9 & 73.33 & 100.00 & 1.00 & High \\
\hline M10 & 48.89 & 86.67 & 0.74 & High \\
\hline M11 & 33.33 & 64.44 & 0.47 & Middle \\
\hline M12 & 40.00 & 82.22 & 0.70 & Middle \\
\hline Average & 47.22 & 83.15 & 0.71 & High \\
\hline
\end{tabular}

Table 2 shows no student who completed minimum Score that set at 75 . This showed the students are not familiar with the indicators of scientific arguments to defend and explain the conclusions made based on experimental results. Posttest showed 10 out of 12 students passed the specified minimum Score. There are two students who did not pass the posttest. This can be due to several factors such as students less engagement in the learning process, some internal factors faced by students, and the lack of the conceptual understanding. Duschl [19] stated that the first thing in mastering the scientific argument is one must have a good working knowledge of concepts like scientific theories, models, and the basic law of a concept [19]. According to Osborne is scientific argument ability one can show the extent to which understanding of the concepts, skills, and scientific argument skills [20].

Overall it can be seen that an increase in the ability of the scientific arguments of prior learning with the book of guided inquiry-based with after using it. Before the learning average score of students' scientific argument abilities is 47.22 , while after learning reaches 83.15. The results showed that the ability of the scientific arguments indicator each level gets a different score. The following chart shows the average score obtained by all students at each indicator.

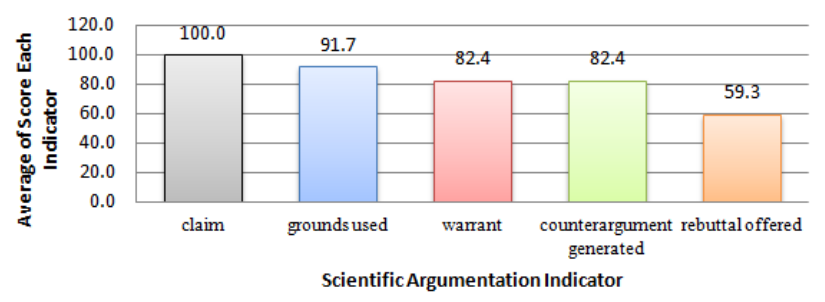

Fig. 1. The average score Indicators of Student Scientific Argument

Based on the diagram in Figure 1 showed that claim to obtain the highest score, while rebuttal offered to obtain the lowest score. The results of this study are supported by research D. Kuhn highest level of scientific arguments are rarely owned by a person [13]. Similar findings were obtained by Farida [21] that the indicator of the ability of scientific argument highest level to get the lowest score [21]. Based on the diagram is known that the classical indicators of rebuttal offered have not reached the minimum score at 75 . This happens because the higher the level indicator of the increasingly complex scientific argument skills also connect between facts and concepts they have. This statement is supported by Wodjack [22] stated that at this stage while making an argument, a valid argument can only be obtained from the critical analysis and make a scientific argument starts from making a logical argument [18]. The statement illustrates how difficult it is to make an argument, especially when students are lack to explore kinds of literature resources. Besides learning by using scientific arguments indicator is only done within four weeks. Though scientific arguments to master the ability to either require longer periods of time [16].

\section{CONCLUSION}

Based on the results, it can be concluded that learning model guided inquiry effective to facilitate the students' 
scientific argument ability on the material transport in plants. This is evidenced by the increase in the value of N-Gain.

\section{REFERENCES}

[1] D. Rosalind, N. Paul, and O. Jonathan, Establishing the Norms of Scientific Argumentation in Classrooms. John Wiley \& Sons, Inc., 2000.

[2] Pickles and B. Patton, "Argumentation and formal argumentation skills in an argumentation-based guided inquiry course," Procedia-Soc. Behav. Sci., vol. 46, pp. 4756-4760, 2012.

[3] D. T. Ucar and S., "The effect of argument-driven inquiry on pre-service science teacher's attitudes and argumentation skills," Procedia-Soc. Behav. Sci., vol. 4, pp. 5035-5039, 2012.

[4] Muslim, "Implementation of the argument dialogical learning model in teaching physics to improve students' scientific arguments sma," vol. 1, no. 2, pp. 12-18, 2015.

[5] W. A. Sandoval and B. J. Reiser, "Explanationdriven inquiry: Integrating conceptual and epistemic scaffolds for scientific inquiry," Sci. Educ., vol. 88, no. 3, pp. 345-372, 2004.

[6] R. Duschl, H. Schweingruber, and A. Shouse, Taking science to school: Learning and teaching science in grades $K-8$. Washington DC: National Academies Press, 2007.

[7] R. Duschl and J. Osborne, "Supporting and promoting discourse argumentation in science education," Sci. Educ., vol. 38, no. 1, pp. 39-72, 2002.

[8] L. K. Berland and D. Hammer, "Framing for scientific argumentation," Res. Sci. Teach., vol. 49, no. 1, pp. 68-94, 2012.

[9] L. K. Berland and B. J. Reiser, "Making sense of argumentation and explanation," Sci. Educ., vol. 93, no. 1 , pp. $26-55,2009$.

[10] C. Wilson, J. Taylor, B. Kowalski, and J. Carlson, "The relative effects and equity of inquiry-based science teaching and commonplace on students' knowledge, argumentation, and argumentation," Sci. Teach., vol. 47, no. 3, pp. 276-301, 2010.

[11] L. Kuhn and B. Reiser, "Students constructing and defending evidence-based scientific explanations," in National association for research in science teaching, 2005.

[12] M. S. Schen, "Scientific argumentation skills development in the introductory biology courses for undergraduates," Ohio State University, 2007.

[13] D. Khun, "Science as argument: Implications for teaching and learning scientific thinking," Sci. Educ., vol. 77, no. 3, pp. 319-337, 1993.

[14] N. R. Council, A Framework for K-12 science education: Practices, crosscutting concepts, and core ideas. Washington DC: National Academies Press, 2011.

[15] L. A. Bricker and P. Bell, "Conceptual of argumentation from science studies and the learning sciences and their implication for the practices of science education," Sci. Educ., vol. 92, no. 3, pp. 473-498, 2008.

[16] V. Sampson, J. Grooms, and J. Walker, Argumentdriven inquiry as a way to help students learn how to Participate in scientific argumentation and craft written arguments: an exploratory study, 95th ed. Wiley Periodicals, Inc, 2011.

[17] D. Katchevich, A. Hofstein, and R. Naaman, "Argumentation in the chemistry laboratory: inquiry and confirmatory experiments," Sci. Educ., vol. 43, pp. 317-345, 2013.

[18] H. Chih-Chao and Et.al, "Enhancing skill in constructing scientific explanations scaffold using a structured argumentation in scientific inquiry," Comput. Educ., vol. 91, pp. 46-59, 2015.

[19] R. Duschl, "Science education in three-part harmony: Balancing conceptual, epistemic, and social learning goals," Rev. Res. Educ., vol. 32, pp. 268-291, 2008.

[20] J. Osborne, "arguing to Learn in Science”: "The Role of Collaborative, Critical Discourse. American Association for the Advancement of Science." New York Avenue, Washington DC, 2010.

[21] I. F. Ch. and W. F. Gusniarti, "Profile Argument Skills Students On Colloid-Developed Concepts Learning Through Inquiry Argumentative," Edusains, vol. 6, no. 1, pp. 32-40, 2014.

[22] J. M. Wodjak, "An Attention-Grabbing Approach to Introducing Students to Argumentation In Science," Biosci. Educ., vol. 15, 2010. 